\title{
Foundations of Tolerance in Turkish Culture ${ }^{1}$
}

\author{
Dr. Osman SEZGIN* \\ Marmara Üniversitesi, Atatürk Eğitim Fakültesi, Göztepe Kampüsü \\ Kadıköy / İstanbul / Türkiye
}

Doç. Dr. Ramazan BİÇER

Sakarya Üniversitesi, İlahiyat Fakültesi, Ozanlar Kampüsü Sakarya / Türkiye

\begin{abstract}
Turkish culture is based on tolerance, the product of the unique Islam-Turkish synthesis. This synthesis is crucial today for a more balanced perception of Islam because it opposes extremism and the terror that is associated with it. The Turkish-Ottoman Empire followed earlier traditions and set up a system based on tolerance towards its ethnically diverse subjects. It was due to this exceptional system assuring stability and freedom of conscience that the Empire was able to hold together people of different religions, languages and races, and to protect and preserve different cultures and languages. This tradition of tolerance and harmony lives on in modern Turkey. Although today there are bound to be certain misinterpretations of Islam, the majority of Turks firmly oppose intolerance and terrorism.
\end{abstract}

\footnotetext{
1 Psikososyal gereklilikler doğrultusunda genişletilmiş ve yeniden yorumlanmış olarak yayınlanmakta olan bu makale, 2006 yılında SSCI tarafindan taranan The European Legacy dergisinde yayınlanmış, yayınlandı̆̆ı dergi ve yazarlardan gerekli izinler alınmıștır.

* Sorumlu Yazar. Tel: +90 $2165219797 \quad$ E-posta: osezgin@marmara.edu.tr

(C) 2012 Kalem Eğitim ve Sağlık Hizmetleri Vakfı. Bütün Hakları Saklıdır.

ISSN: $2146-5606$
} 
Keywords: Tolerance; Freedom of conscience; History; Culture; Social balance.

\section{Türk Kültüründe Hoşgörünün Temelleri}

\section{Özet}

Türk kültürü, Türk-İslâm sentezinin eşsiz bir ürünü olan hoşgörü üzerine kuruludur. Bu sentez, daha dengeli bir İslâm algısı için, bugün hayatî bir öneme sahiptir; çünkü İslâm aşırılığa (fanatikliğe) ve ona bağlı terörizme karşıdır. Osmanl-Türk Devleti (İmparatorluğu) ilk baştaki geleneklere uymuş ve farklı etnik unsurlara hoşgörüye dayalı bir sistem kurmuşlardır. İşte, istikrarı ve vicdan özgürlüğünü teminat altına alan bu istisnaî sistemden dolayıdır ki; imparatorluk (Devlet) farklı din, dil ve ırklardan insanları bir arada tutabilmiş, farklı kültür ve dillere sahip çıkabilmiş ve muhafaza edebilmiştir. Bu hoşgörü ve ahenk geleneği bugün modern Türkiye'de yaşamaktadır. Bugün İslâm'ın kesinlikle yanlış olan yorumlarına rağmen, Türklerin büyük çoğunluğu katı bir şekilde hoşgörüsüzlüğe ve terörizme karşıdır.

Anahtar kelimeler: Hoşgörü; Vicdan özgürlüğ̈̈; Tarih; Kültür; Toplumsal denge.

\section{Introduction}

Ever since Islam was born, Muslims had made immense leaps forward in the areas of science, technology and culture of tolerance. During the Middle Ages, the Islamic World had a very significant impact upon Europe, which cleared the way for the Renaissance and the Scientific Revolution in the West.

In the same period, the situation was totally contrary in Europe and Europe was in the Dark Ages. According to Muslims, Europe was backward, unorganized and carried no strategic importance in the world. Nevertheless, the Catholic Church, which at the time was the strongest institution in Europe, successfully convinced Christians in Europe that the Mus- 
lims widening their power and influence in the East, Central Asia and Anatolia towards the West were infidels.

However Anatolia, taking place between East and West and linking two continents (Asia and Europe) each other where one of the biggest and the most glorius civilizations of the world was born in has a qualified and distinguished name as a centre of tolerance, broad-mindedness and plurality, especially since 13th century till today

Throughout the 12th and 13th centuries, Anatolia which acquires its present name as Turkey, with the arrival of Turks from Central Asia in the 11th century $\mathrm{AD}$, was totally in a real turmoil. On one side, competing Turkish tribes were fighting among themselves, on the other hand the Byzantines were trying to recapture their land while Crusaders coming from the West provoked by the church with religious hatred feelings against Muslims were passing through Anatolian lands to reach Palestine leaving destroyed villages and killed people their behind. Turks in Anatolia, in the meantime were facing another destroying attacks by Mongols coming form East during the same period.

Despite all these cathastrophic effects within the 13th century, Anatolian lands where mostly Turks lived became contrarily a place that Turkish Muslim thinkers like Mevlana, Yunus, Hacı Bektaş were introduced their well known thinkings on human love, tolerance, plurality, broad-mindedness etc. still influencing universal culture and humanity.

According to the today's Western intellectuals, the Muslim world in the 13th century with its development of the culture of philosophy, science, 
mathematics, astronomy, physics, chemistry and medicine, led the world. The Muslim world once possessed in its hands the keys to the future prosperity that technology could deliver. If the Muslim world had been able to continue on the Quranic commands on scientific research, the cause of human progress would have been advanced by about five hundred years.

They believe that the modern technology industry would not exist without the contributions of Muslim scientists as Mrs.Carly Fiorina, a former prominent figure in US business world and a new politician, said in her very important call to world leaders in 2001.

Mrs. Fiorina, Hewlett-Packard's (HP) Chairman and CEO at that time delivered a speech in Minneapolis, Minnesota on September 26, 2001. The title of her speech was 'Technology, Business and Our Way of Life: What's Next'.

She said in her well designed speech that "There was once a civilization that was the greatest in the world. It was able to create a continental super-state that stretched from ocean to ocean, and from northern climes to tropics and deserts. Within its dominion lived hundreds of millions of people, of different creeds and ethnic origins."

"One of its languages became the universal language of much of the world, the bridge between the peoples of a hundred lands. Its armies were made up of people of many nationalities, and its military protection allowed a degree of peace and prosperity that had never been known. The reach of this civilization's commerce extended from Latin America to China, and everywhere in between." 
"And this civilization was driven more than anything, by invention. Its architects designed buildings that defied gravity. Its mathematicians created the algebra and algorithms that would enable the building of computers, and the creation of encryption. Its doctors examined the human body, and found new cures for disease. Its astronomers looked into the heavens, named the stars and paved the way for space travel and exploration."

"Its writers created thousands of stories. Stories of courage, romance and magic. Its poets wrote of love, when others before them were too steeped in fear to think of such things."

"When other nations were afraid of ideas, this civilization thrived on them, and kept them alive. When censors threatened to wipe out knowledge from past civilizations, this civilization kept the knowledge alive, and passed it on others."

"While modern Western civilization shares many of these traits, the civilization I'm talking about was the Islamic world from the year 800 to 1600, which included the Ottoman Empire and the courts of Baghdad, Damascus and Cairo, and enlightened rulers like Suleiman the Magnificent."

"Although we are often unaware of our indebtedness to this other civilization, its gifts are very much a part of our heritage. The technology industry would not exist without the contributions of Arab mathematicians. Sufi poet-philosophers like Rumi challenged our notions of self and truth. Leaders like Suleiman contributed to our notions of tolerance and civic 
leadership."

"And perhaps we can learn a lesson from his example: It was leadership based on meritocracy, not inheritance. It was leadership that harnessed the full capabilities of a very diverse population -- that included Christianity, Islamic, and Jewish traditions."

"This kind of enlightened leadership -- leadership that nurtured culture, sustainability, diversity and courage -- led to 800 years of invention and prosperity."

Speaking just after two weeks from September 11 attacks to twin towers of World Trade Center and Pentagon in 2001, Mrs.Fiorina concluded her speech with such words as follows: "In dark and serious times like this, we must affirm our commitment to building societies and institutions that aspire to this kind of greatness. More than ever, we must focus on the importance of leadership -- bold acts of leadership and decidedly personal acts of leadership."

Following the attack of September 11, there has been growing interest in Islam and the subject of tolerance. Various western writers have accused Islam of being intolerant and Moslem writers have responded to these accusations by drawing attention to the tolerant aspects of Islam. All human societies seem to have developed forms of religious worship, which changed according to their specific cultural contexts. In Turkey, for example, where Islam is the main belief system, there are bound to be certain misinterpretations and misunderstandings of the dominant religion. However, radical Islamic forms will be found to have their roots in the Middle 
East rather than in a secular state like Turkey where tolerance derives from a unique cultural phenomenon: the Turkish-Islamic synthesis. This synthesis is crucial today for a more balanced perception of Islam because it opposes extremism and the terror that is associated with it.

Religious tolerance has a specific signification. It connotes a refraining from prohibition and persecution, but it suggests latent disapproval and usually refers to a condition in which the freedom it permits is both limited and conditional. It is not equivalent to religious liberty or religious equality. It assumes a religious authority which might have been coercive, but which, for reasons of its own, is not pushed to extremes (James, Selbic and Gray, 1980; Lalande, 1928).

Tolerance is an attitude that enables one to tolerate principles and practices of others despite one's own desires or even dislikes. It does not imply genuine sympathy for what is tolerated, but its absence (Temimi, 1994). The motivation to tolerate things we do not like may be explained by our wish not to be aggressors or disturbers of the peace: we do not wish to impose our ideas on others and thereby evoke hostile criticism. By giving a fair deal to other religions we want to peacefully present the proper form of our religion. In order to show its perfection, we need to appeal directly to the hearts of others without resorting to intimidation or force. In Turkish culture the term tolerance always implies reciprocity (Brusse, 2004; Korkmaz, 2000).

It may be correct to say that the Turkish people are on the side of dialogue. They know that dialogue in a framework of the free exchange of 
ideas is the only peaceful alternative to mankind. Islam does not castigate a person's private conduct: the prophet of Islam recommends that individuals who deviate from religious norms-even if they commit adultery-should keep their sins to themselves and seek God's forgiveness. Most religions set limits to tolerance; in fact there is no religion or legal system that is absolutely tolerant. Islamic law, for example, seeks to protect social order (Ahmad, 1988). It encourages people to do well and discourages them from doing evil. At present, Islam prohibits any campaigning for drug decriminalization or any practices that may undermine the family system (Haleem, 1998).

\section{Tolerance in Islam}

We learn from history that some leaders enforce their ideas on others. But in Turkey today people believe that the time of doing so is over. In fact, Islamic teaching never permits the coercive imposition of faith. Islam has been on the side of religious and cultural pluralism and coexistence since its beginning. It affirms that faith, commitment to religion and to a worldview are primarily moral decisions. Men and women have to take such decisions freely and voluntarily. Any compulsion on this count is abhorrent and can only breed hypocrisy, a moral disease that Islam wants to cure and eradicate. The "superiority" of a system is established on the grounds of its moral excellence and its acceptance or rejection should be free. So The Koran affirms as a moral and a historical premise that the differences among human beings, in terms of wealth, race, color, language and physical features are natural, and that philosophical and religious pluralism is the norm rather than an anomaly (Koran, 5:48). 
Some may point to religious extremism in the course of the Islamic history. Perhaps the persons who believed in a system firmly, especially in those based on religious conviction, are supremacist in a sense: believers are considered as having special rituals distinguishing them from adherents of other faiths. But the supremacist creed of puritan groups is distinctive and uniquely dangerous. This form of suprematism has a powerful nationalist component that is oriented towards cultural and political dominance. Supremacist groups are not satisfied with living according to their own dictates, but are disappointed with all other ways of life. They do not merely seek self-empowerment but aggressively seek to dominate, and/or destroy others. The crux of the matter is that all ways of life lived outside the frame of the law are conceived of as an offense against God that must be actively resisted.

But the phenomenon of Muslim fanaticism is hardly surprising. Most religious systems suffered at one time or another from extremism and Islam suffered from this too. The religious extremists known as the Khawarij (literally, the secessionists), for example, slaughtered a large number of Muslims and non-Muslims, and were even responsible for the assassination of the Prophet's cousin and companion, the Caliph Ali b. Abi Talib during the first century of Islam. Descendants of the Khawarij survive today in Oman and Algeria, but after centuries of bloodshed, they have become more moderate. Similarly, the Qaramites and Assassins, for whom terror was a raison d'etre, earned unmitigated infamy in the writings of Muslim historians, theologians, and jurists. Again, after centuries of bloodshed, these two groups, which exist today in small numbers in 
North Africa and Iraq, have learned the lesson of moderation. The essential lesson of history suggests that extremist groups have been thrown out of mainstream Islam; they have been marginalized and are seen as heretical aberrations of the Islamic message.

But the terrorist attacks of recent years have focused public attention on Islamic theology. The name of the religion, Islam, given in the Koran by God himself, means "devotion to God." God is not the Lord of the Muslims but the Lord of all human beings and of all the worlds (Rabbi al Alamin): "We have honored the Children of Adam" (Koran, 17:70)-all Children of Adam are "chosen by God" to be honored. God addresses Muslims and followers of other religions.

Koran does not allow to force or disturb people of different beliefs and advises to live peacefully with them, this is even true in their relations with polytheists, who stand at the opposite extreme of the fundamental monotheistic belief of Islam (Koran, 60:8; 49:13).

The variety of colors, tongues, and races is declared to be a sign of God's power and mercy (Koran, 30:22; 49:13), which should lead to closeness rather than to discrimination or intolerance. These two verses are complementary. They imply that when God is recognized in His true majesty and dominion, there should be no compulsion in religion. Men choose their own paths -allegiance or opposition- and being cut off from the light of truth is sufficient punishment for those who oppose (Koran, 2:225-56). These instructions, which recur in the Koran, are part of the main messages of Islam: they show that tolerance has been a natural and 
inseparable part of Islam from its beginning. It did not begrudgingly tolerate non-Muslims but welcomed them to live freely in Muslim society. At the height of its success, the Koran sets the principle, la ikrahafi din-"There is no compulsion in religion" (Koran, 2:256). Thus the decision to be a believer in Islam is a completely personal choice.

Islam tolerates and acknowledges the liberty of other religions; it decrees respect of the beliefs and rights of members of other religions and ensures that they be justly treated (Aydın, 1998). The rise of secularism in Europe in the seventeenth century with its principles of freedom of conscience and faith has applied to Islam for a very long time. Throughout history, Muslims who obeyed the decrees mentioned above did not mistreat people of other faiths. In the conquered lands, both Christians and Jews enjoyed freedom of worship. In the words of Sir Thomas Arnold: "The Muslim tolerance showed after they defeated the Christians in the first century" is worthy of mention (Arnold, 1974). We can also cite a hadith: "Anyone who hurts a Christian and a Jew should find me opposing him."

In Spain under the Umayyads and in Baghdad under the Abbasid governments, Christians and Jews were admitted to the schools and universities just like the Muslims; they were even granted lodgings in hostels at the cost of the state. When the Moors were driven out of Spain, the Christian conquerors persecuted the Jews. Those who were fortunate enough to survive fled to Morocco or to the Ottoman Empire, where their descendants still live in separate communities and still use their own language, Ladino (Judeo-Spanish). The Muslim empire was a refuge for 
inseparable part of Islam from its beginning. It did not begrudgingly tolerate non-Muslims but welcomed them to live freely in Muslim society. At the height of its success, the Koran sets the principle, la ikrahafi din-"There is no compulsion in religion" (Koran, 2:256). Thus the decision to be a believer in Islam is a completely personal choice.

Islam tolerates and acknowledges the liberty of other religions; it decrees respect of the beliefs and rights of members of other religions and ensures that they be justly treated (Aydın, 1998). The rise of secularism in Europe in the seventeenth century with its principles of freedom of conscience and faith has applied to Islam for a very long time. Throughout history, Muslims who obeyed the decrees mentioned above did not mistreat people of other faiths. In the conquered lands, both Christians and Jews enjoyed freedom of worship. In the words of Sir Thomas Arnold: "The Muslim tolerance showed after they defeated the Christians in the first century" is worthy of mention (Arnold, 1974). We can also cite a hadith: "Anyone who hurts a Christian and a Jew should find me opposing him."

In Spain under the Umayyads and in Baghdad under the Abbasid governments, Christians and Jews were admitted to the schools and universities just like the Muslims; they were even granted lodgings in hostels at the cost of the state. When the Moors were driven out of Spain, the Christian conquerors persecuted the Jews. Those who were fortunate enough to survive fled to Morocco or to the Ottoman Empire, where their descendants still live in separate communities and still use their own language, Ladino (Judeo-Spanish). The Muslim empire was a refuge for 
all those who fled from the Spanish Inquisition.

The pronouncements of Islam on justice deserve special attention. The Prophet Mohammed and the Four Caliphs were the executive heads of the state, but at the same time they were subjected to the laws of the land like all ordinary citizens. This tradition, established by Mohammed himself, does not grant the head of a state any privileges above the law. One example of this is that the First Caliph, Abu Bakr, was invited to the law court by the most humble subjects and even by a non-Muslim (Hamidullah, 1961).

Islamic tolerance allows non-Muslims to live according to their customs, even if these are forbidden by Islam. Thus Christians are allowed to breed pigs, eat pork, make and drink alcohol in Muslim countries. Perhaps it would not be asking too much from them to refrain from these out of respect for Islamic society, since these practices are not obligatory. Moreover, non-Muslims were judged according to their own religious laws, which were incorporated in Ottoman law (Günay, 1990).

The multiplicity of socio-cultural groups in a Muslim state is the counterpart of the ontologically defined political power structure, which assumes a horizontal segmentation of the governed. In Islamic history the state was considered a confederation of social groups under the patronage of a central political power. The privilege of becoming a protected minority via an act of dhimmiship was only given to the followers of a prophet to whom a sacred book was revealed, which is why these communities were called ahl al-kitab. The rights of these communities were 
specified in the Koran.

One of the main features of the Islamic civilization during the Middle Ages was its liberal and tolerant attitude towards members of other religions. Subject peoples were treated as ahl al dhimmah; they enjoyed freedom of worship and state protection in return for payment of a very moderate poll tax, the jizyah. In the early centuries of Islam this applied only to people of revealed religions -Jews, Christians and Sabeans, but later it was extended to the fire- worshipping Zoroastrians, the heathens of Harran, pagan Berbers of North Africa and followers of other creeds. Hindus were also included among the dhimmis, "those who enjoy protection." (Hitti, 1986).

Some western writers cite this as an example of Muslim intolerance, distorting the meaning of dhimmis, as well as the use of the jizyah tribute. Even in levying the poll tax the Muslims exhibited a humane and tolerant attitude towards non-Muslims: the moderate sum of one to four dinars per year was levied only from those who were capable of military service. The tax varied at times according to income; it did not apply to women, children, monks, the old and the crippled, the poor and slaves. In return for it, the Muslim state assumed responsibility for the protection of the life and property of members of these communities, granting them full religious and cultural freedom. They were exempted from military service as well as from the "poor-tax" Muslims paid for community charity (Durant, 1962).

Sometimes the jizyah was one dinar a year for every able-bodied 
male who could fight in the army except monks. As non-Muslims they were not obliged to join the army, but the jizyah was their contribution to the defense of the state they lived in. This may be compared to the much higher zakah tax obligatory to Muslims as a pillar of Islam, male or female, young or old, part of which is spent on defense. Muslims, moreover, had the obligation to serve in the army. However, when non-Muslims chose to do military service they were exempted from the jizyah (Günay, 1990).

The Koran, hadiths and tradition allowed non-Muslims to have their own laws, to be judged by their own judges in their own courts in religious or social cases without the interference of the Muslim authorities (Hamidullah, 1961). At the time of Mehmet the Conqueror (1432-81), for example, a court in the Fener Rum Orthodox Patriarchate was established and the sentences passed there were upheld by the Ottoman government (Göyünç, 2000). During the reign of Omar, Jean, The Bishop of Mikou (464-575/6) also confirmed the Muslim's tolerance towards members of other religions. He witnessed the conquest of Egypt: "Amr b. al-As did not take anything from the churches and did not plunder or seize the properties of the churches. And the Muslim state did not interfere in the business of the Christians." After conquering Jerusalem, Caliph Omer wrote a "proclamation of warrant":

- Their churches are not to be turned into mosques; their homes and buildings are not to be destroyed because of their faith.

- Christians are not to be oppressed because of their faith (Öztürk, 1998). 
When Omar entered Al-Quds, he was received by the Patriarch who toured the town with him until they arrived at the Church of Resurrection and entered. At prayer time, Omar told the Patriarch that he wanted to perform prayer. The Patriarch answered: "You may pray where you are sitting." On seeing that he was sitting in the very middle of the Church, Omar feared that Muslims would follow suit. They would say: "Since Omar has prayed here, we are all entitled to pray here too." They might even take the Church by force in violation of the provisions of the Omar Covenant that stipulated respect for Christians' churches, which had to be left to the Christians. They would think that what Omar had done with the consent of the Patriarch was an amendment of the conditions stipulated in the Covenant. Omar came out of the Church and prayed on its threshold. Yet, he ordered to stipulate in writing that no collective prayer be performed on that spot, nor a call to prayer be made therein. Omar then went to the Rock, and built the Mosque of the Rock (Tabari, 1987).

The governors after Omar followed these instructions. When the Ottoman Sultan Yavuz Selim seized Jerusalem in 1517, he passed an edict to protect the rights of its non-Muslim inhabitants (Karakoç, 1919).

\section{Tolerance and Turkish Culture}

Islamic civilization may be divided into three periods. It first expanded from the Muslim caliphate in the East Mediterranean in the late seventh and first half of the eighth centuries to provinces bordering on the Byzantine Empire in Palestine, Syria and Egypt; this is considered the first great moment of Islamic history. This coincided with the expansion of Muslim rule to North Africa, Spain, and Sicily, with the establishment of 
the Arab kingdoms in Andalusia (up to the fifteenth century) and Muslim rule in Sicily (up to the fourteenth century). This can be considered as the second moment of Islamic history. Around the same period, Muslim Turks settled in Anatolia, formerly under Byzantine rule, and from the fourteenth century onwards the Ottomans gradually expanded their control from Anatolia to the west and east. The ensuing state and civilization represents the third major moment in Islamic history. Throughout these centuries the aforementioned principles of tolerance towards religious minorities were upheld.

The Turks did not intervene in the affairs of the non-Muslim communities living on their territories. The Seljuk government respected the religious autonomy of their subjects (Turan, 1971). Armenian and Georgian reports attest to this: "Melikşah's heart was full of tenderness and kindness towards Christians. He treated the children of Jesus very nice. He brought welfare, peace and happiness to the Armenian people."(Kocaş, 1967; Brosset, 1849). The chronicles of the Alexandrian Patriarch refer to Mesut I (1116-56), whose subjects were mostly Greeks who preferred his tolerant rule, as confirmed by Byzantine sources (Mufarrig). Further evidence is found in E. Ruclus: "The conquest of the Turks does not penetrate into the depth of the heart of individuals. For this reason the freedom granted to different communities in Turkey is more perfect than in the countries of Europe." Churches and mosques were built side by side in the city of Duveyn. Marriages between Muslim governors and Georgian and Armenian princesses took place (Minorsky, 1953).

One of the major indicators of cultural pluralism in the Ottoman 
State was millet "community" system. The Ottoman policy regarding non-Muslims was based on this system that divided them according to religion and sect and regulated the relationship not only between the communities and the state but also among the communities themselves. The Ottoman state consisted mainly of Muslims and non-Muslims and what determined the status of the individual and his relationship with the state was either religion or ethnic denomination. The Muslims formed the Millet-i Islam "Muslim nation," regardless of race, language or sect, comprising Turks, Arabs, Kurds, Albanians, Bosnians and so forth. The non-Muslims were organized in different millets according to their religious affiliation whether Orthodox (Greeks, Bulgarians and Serbs), Catholic, Gregorian (Gregorians, Armenians), or the synagogue (Jews).

The millet system was initiated by Mehmed the Conqueror after the conquest of Istanbul. According to his decree, the Orthodox Patriarch, elected by his followers, was the head of all Orthodox Christians and attended the Divan-i Humayun (Imperial Council) on behalf of his community. This was later extended to other communities as well. Thus the state granted non-Muslims religious freedom and guaranteed the security of their lives and property.

The sixteenth-century Ottoman writer Kınalızade Ali Efendi's definition of "civilized (medenî) society" aptly expresses the function of the millet system: "Civilized society consists of different groups and rival millets which come together, come to an agreement and live in order and in harmony" ("Pes malum olsun ki temeddun ki tavaf-i muhtelife ve umem-i mutebayinenin ictima-i am ve teelluf ve intizamindan ibarettir"). 
The non-Muslims enjoyed autonomy in many spheres, with every millet establishing its own organizations and institutions. The Ottoman government limited itself to the functions of administration, finance, the military and the judicial system. All other matters -education, communication, social security, health, religious services, marriage, dowry, alimony and inheritance- were run by the millet. Each millet had its own law courts and the Ottoman government had to abide by their rulings. The leaders of the communities could impose taxes, control the press and determine the school curriculum. There was no government control over churches and schools; and any non-Muslim could sue a community leader or a Muslim officer and appeal to the Imperial Council. While non-Muslims applied their own laws in private and family matters they were subject to the Muslim penal code. They had to pay two kinds of tax: the jizya (in return for protection; from which women, children, the old etc. were exempted) and the kharaj (land tax).

The founder of the Ottoman Empire, Osman Bey, maintained the religious rights of the Christians. When he reached Hagia Sophia after the conquest of Constantinople in 1453, Conqueror Sultan Mehmet II granted them full rights and reorganized the staff of the Orthodox Greek Patriarchate (Phrantzes, 1838). The church elected Gennadios as the Patriarch of Constantinople and the Sultan bestowed on him the title "Millet başı" (Head of Nation) (Phrantzes, 1838). Sultan II issued an edict that the Patriarch and priest were not to be disturbed, exempting them from various services and taxes. Their churches were to be kept and not changed into mosques. He guaranteed their freedom of worship and allowed them to 
follow their customs, marriage laws and funeral rites. The Patriarch and Vizier had equal status and the Patriarch was also granted protection (Cevdet Pasha, 1309).

Süleyman the Magnificent reinforced these privileges when, in response to Francois I's request, he forbade a church in Jerusalem to be changed into a mosque (Fraserli Mehdi, 1325; Şahin, 1980). After the conquest of Cyprus in 1571, Sultan Selim II issued an edict to the governor-general (Beylerbeyi), the kadl (Muslim judge) and the Defterdar (minister of finance), specifying various rights to non-Muslims. Non-Muslim governors expressed their gratitude to Ottoman rulers, as may be seen in a document known as Patrik-i İstanbul-i Rum ve Asitane'de Mukim Cemaat-i Metropolitan (Kireçyan, 1980).

Another example of religious tolerance relates to the Jews. The relations of Turks and Jews had a long history, going back to the early days of the Ottoman Empire. It was, however, the confluence of historical circumstances in the second half of the fifteenth century that led the Ottomans to show particular interests in the Jews who were expelled from Spain. Following the conquest of Constantinople, the crusading fervor in Europe had reached its peak. On the other hand, the Spanish reconquista, resumed against the Muslims of al-Andalus, stirred an intense spirit of Jihad in the Islamic world (İnanc1k, 2002).

Yet another example is Sultan Mehmed II's pledge given in Bosnia and Herzegovina on 28 May 1463, granting safety and security to the Franciscans: 
I, Sultan Mehmet Han, inform the entire world that those who posses these imperial edicts, the Bosnia Franciscans, are in my good graces and I hereby command: let no one bother or disturb neither those mentioned nor their churches. Let them dwell in peace in my empire. And let those who have become refugees be allowed to do so and be safe. Let them return and let them settle in their monasteries without fear in all countries of my empire. Let no one attack, insult or endanger their life or their property, nor the property of their church.

Similarly, in May 1517, on entering Jerusalem, Sultan Selim issued an edict to the Armenian Patriarch Serkis guaranteeing all previous religious rights and institutions of the Christians.

At the same time in 1830 Sultan Mahmud II declared:

I distinguish among my subjects, Muslims in the mosque, Christians in the church and Jews in the synagogue, but there is no difference among them in any other way. My affection and sense of justice for all of them is strong and they are all indeed my children. There is no difference between them on other days (Karal, 1982).

In another speech at Shumnu (Shumen in Bulgaria), on 5 May 1837, he said:

Oh Greeks, Armenians and Jews! All of you, just like the Muslims, are God's servants and my subjects. You have various religions and you are all under the protection of the laws 
of the state and my royal will. Pay the taxes assigned, for they are used for your security and welfare.

Some reforms were introduced in the millet system after Tanzimat Fermani/the Reform Firman (1839) and Islahat Fermani/the Improvement Firman (1856), in response to various demands and new regulations took effect on 25 April 1861 "Rum Patrigi Nizamati'..." (Regulations relating to the Greek Patriarch). Similarly, "Ermeni Milleti Nizamnamesi" (Regulations relating to the Armenian community) became effective on 18 March 1863, and "Yahudi Milleti Nizamnamesi" (Regulations relating to the Jewish community) on 22 March 1865.

This favorable environment enabled people of Armenian and Jewish origin to hold important posts in the Ottoman administration and bureaucracy. Among the Armenians, Artin Dadyan Pasha (1830-1901), Kapriyel Noradunkyan Pasha (1852-1941) and Ohannes Kuyumcuyan Pasha (1858-1933) served in the Ministry of Foreign Affairs; and Agop Kazayan Pasha (1833-91) and Mikeal Portukal Pasha (1842-97) worked in the Ministry of Finance. Sakiz Ohannes Pasha worked in the Ministries of Education, Foreign Affairs and Finance, while Garabet Artin Davut Pasha (1816-73) served in the Ministries of Foreign Affairs and Interior Affairs and later became Governor of Lebanon (1861). Dr Kapriel Pasha Sevyan (1822-1900), Dr Istepan Pasha Aslanyan (1822-1902), Dr Dikran Pestimalciyan Pasha (1840-94) and Dr Antranik Gürcikyan Pasha (1819-94) also held important positions.

Jews too held important posts in Ottoman lands. Among them were 
sadaret kaymakams, military officers, consuls, judges and pashas. For example, Leon of Izmir served as Ottoman Consul in Paris. Many Jewish physician-officers like Ilya Kohen, Isak Moho, Albay Ilyas Bey Modyano served in the Ottoman army. Other physicians, like Jak Pasa Mandil, worked as civil servants. Judges, like Samuel Efendi in Serres, and Haskiel Gabay in Uskudar, public prosecutor Muiz Zeki Albala in Siroz and Manastir are just a few examples of Jews who held important positions in the Ottoman bureaucracy. We conclude with a striking example of the Darulaceze, a charitable institution established in Istanbul in 1895 as a house for the needy, which includes a mosque, a church and a synagogue that have remained active until today.

Our overview of Islamic attitudes to people of other cultures and religions demonstrates a spirit of genuine pluralism. This, in fact, is the spirit behind many centuries of peaceful coexistence of peoples of different religions and cultures under Ottoman rule. The multinational, multicultural and multireligious system it established ensured tolerance and harmony among its peoples. It is a system often referred to in academic discourse on the dialogue and coexistence of civilizations. And especially so with regard to translating its exemplary features-religious and ethnic tolerance-providing peoples of different faiths, languages and races the possibility of living and working together in peace on the basis of equality, the rule of law and universal human rights, for only these would constitute a real culture of peace.

Briefly, the primary mechanism, which the Ottomans used to manage the internal affairs of their multireligious and polyethnic empire, 
from the fifteenth century to the twentieth, was the millet system. Under this system, minorities enjoyed a wide latitude of religious and cultural freedom, as well as considerable administrative, fiscal, and legal autonomy under their own ecclesiastical and lay leaders. The term millet (community) originally meant both a religion and a religious community. In the nineteenth century, while still retaining its original meaning, it also came to denote such modern concepts as nation and nationality. The Ottoman millet system had its origins in earlier Middle Eastern states, both Muslim (Umayyad, Abbassid) and non-Muslim (Persian, Byzantine), and it was not, therefore, an original Ottoman innovation, but it is collected from Seljuks, Abbasid and Byzantine rules. The Ottoman contribution was mainly to regulate and institutionalize it, pay greater attention to its proper operation, and bring it down from medieval times to the twentieth century (Braude and Lewis, 1994).

\section{Conclusion}

Religion is a reality for individuals and societies. In Turkey there are bound to be certain misinterpretations of the main religion, Islam; yet most Turks oppose religious intolerance and terrorism (Ozankaya, 1979; Denker, 1997; Gündüz, 1996; Ergil, 1980; Tacar, 1999). For, according to Islam, "nobody should be killed unjustly." This is why Muslims, Christians, and Jews have been living in peaceful coexistence in the same region for many centuries. Mosques, churches, and synagogues stand side by side in Istanbul and other Anatolian cities. The people in Turkey live in the same way as in the past although they believe in different religions. No one is accused or denounced for his beliefs. 
Although radical ideas are incompatible with Turkish culture, some marginal groups have adopted radical ideas originating in neighboring countries. We should consider the movement of terror and intolerance in Islamic countries very carefully. Does it really spring from religious anxiety? Terrorism is a complex phenomenon. Like other forms of violence, there is no single reason why people engage in terrorism, and there is no simple solution to the problems it poses. But if we wish to move beyond vengeance and seek a solution, we must truly try to understand and effectively address the circumstances that give rise to terrorism and foster it. In our search for a solution, we found that economic and political developments play a critical role. They may not be the whole answer but they are clearly an important part of it (Dumas, 2003).

Terrorism has no religion, which means that all terrorists are criminals, regardless of their identities and motives, their country of origin or affiliation. Turkish society condemns every kind of terrorism especially when it is carried out in the name of religion. Intolerance is one of the causes of terrorism; but both the teachings of Islam and Turkish culture uphold tolerance and oppose religious terror.

\section{References}

Ahmad, M. (1988). There shall be no coercion in religion. In L. J. Hammann, H. M. J. Buck and M. McTighe, (Ed.), Religious traditions and limits of tolerance (pp.83). Chambersburg, PA: Anima Books.

Arnold, T. (1974). The preaching of Islam. New York: Ams Press.

Aydin, M. (1998). Türk toplumunda dini hoşgörünün temelleri. The Review 
of the Faculty of llahiyat University of Selçuk, 8, 7.

Başbakanlik Arşivi Genel Müdürlüğü Mühimme Defteri (Prime Ministry Ottoman Archives, Numbered Notebook of Important Affairs). 21 September 1571, The Firman (The Decree) of Sultan Selim II on the Conquest of Cyprus, No. 12. İstanbul.

Brosset, M. (1849). Histoire de la Georgie, 1. Petersburg: Academie Imperiale des Science.

Brusse, W. A. (2004). The european union, religion and Turkish Islam. In (R. T. Griffiths and D. Özdemir, (Ed.), Turkey and the EU enlargement, (pp. 79-83). İstanbul: İstanbul Bilgi University Press.

Cevdet Pasha (1309). Tarih, 11. İstanbul: Matbaa-1 Osmaniye.

Denker, M. S. (1997). Uluslararası terör, Türkiye ve PKK. İstanbul: Boğaziçi Yayınları.

Dumas, L. J. (2003). Is development an effective way to fight terrorism? In V. V. Gehring, (Ed.), War after September 11, (pp. 74-75). Lanham: Rowman and Littlefield.

Durant, W. (1962). Histoire de la Civilisation. (C. Mourey, Trans.). Lausanne: Societe Cooperative Editions Rencontre.

Ergil, D. (1980). Türkiye'de terör ve şiddet. Ankara: Turhan Kitabevi.

Fraserli Mehdi, (1325). Imtiyazat-ı ecnebiyyenin tatbikat-ı hazirasi. Samsun: Matbaa-1 Cemil.

Göyünç, N. (2000). Türk toplumunda hoşgörü. The Review of Academic Researches, 2(5), 165.

Günay, Ü. (1990). Tendance de tolerance religieuse dans la culture Turque. 
The Review of the Faculty of Ilahiyat, University of Erciyes, 15, 12-13.

Gündüz, M. (1996). Basın ve terör. İzmir: Saray Medikal Yayıncılık.

Haleem, M. A. (1998). Tolerance in Islam. The Islamic Quarterly, 42(2), 96-97.

Hamidullah, M. (1961). İslam'a giriş. (K. Kuşçu, Trans.). İstanbul: Sönmez Neşriyat.

Hammann, L. (1988). The limits of tolerance. In L. J. Hammann, H. M. J. Buck and M. McTighe, (Ed.), Religious traditions and limits of tolerance (pp. 1-5). Chambersburg, PA: Anima Books.

Hitti, P. K. (1986): History of the Arabs. London: Macmillan.

İnalcık, H. (2002). Foundation of Ottoman-Jewish cooperation. In A. Levy, (Ed.), Jews, Turks, Ottomans: A shared history, fifteenth through the twentieth century (pp. 3). New York: Syracuse University Press.

James, H., Selbic, A. and Gray, H. (Ed.). (1980). Encyclopedia of religion and ethics (pp. 12-360). Edinburgh: T.T. Clark; New York: Charles Scribner's Sons.

Karakoç, A. S. (1919). Kulliyat-ı Kavanin. Ankara: The Library of the Association of Turkish History.

Karal, E. Z. (1982). Non-muslim representatives in the first constitutional assembly, 1876-1877. In B. Braude and B. Lewis, (Ed.), Christians and Jews in the Ottoman Empire, 1(pp. 388). New York: Holmes and Meier.

Kireçyan, B. (1980). Facts from the Turkish Armenias: Realites exprimees par les Armeniens turcs. İstanbul: Jamanak Publica- 
tion.

Kocaş, S. (1967). Tarih boyunca Ermeniler ve Türk-Ermeni ilişkileri. Ankara: Altınok Matbaası.

Koran.

Korkmaz, S. (2000). Türklerde hoşgörü. The Review of Erciyes University Social Sciences Institute, 9, 491.

Lalande, A. (1928). Vocabulaire technique et critique de la philosophie. Paris: Librairie Felix Alcan.

Levy, A. (1994). Introduction. In A. Levy, (Ed.), The Jews of the Ottoman Empire (pp. 1-150). Princeton, NJ: Darwin.

Minorsky, V. F. (1953). Studies in caucasian history. London: Taylor's Foreign Press.

Mufarrig, M. M. Siyar aba al batarika: Histoire des patriarches de I'église d'Alexandrie. Paris: Biblioteque National.

On the millet system and its transformation, Braude, B. \& Lewis, B. Introduction to vol. 1 of Christians and Jews in the Ottoman Empire, 1-34

Ozankaya, Ö. (1979). Türkiye'de terörün etkenleri ve çözüm yolları. The Review of the Faculty of Political Sciences, 34(1), 51-61.

Öztürk, L. (1998). Asr-ı saadetten haçlı seferlerine kadar İslam toplumunda Hristiyanlar. İstanbul: İz Yayincilik.

Phrantzes, G. (1838). Chronicon, I. Bekker, (Ed.), 30-305, Bonn: Lib. III, chap. 11, Migne PG 156, col. 894.

Schemsi, K. (1919). Turcs et Armeniens devant I'Histoire. Genere: Impri- 
meric Nationale.

Şahin, M. S. (1980). Fener Patrikhanesi ve Türkiye. İstanbul: Ötüken Neşriyat.

Tabari, J. (1987). Tarikh al-Umam wal Muluk, 4. Beirut: Dar al-Kutub al-Ilmiyya.

Tacar, P. Y. (1999). Terör ve demokrasi. Ankara: BilgiYayınevi.

Temimi, A. (1994). Tolerance Islamique et tolerance chretienne: Est-ce Une equation impossible. In Etudes sur les relations Islamo-Chretiennes (9). Zagvan: Ceromdi.

Turan, O. (1971). Selçuklular ve İslamiyet. İstanbul: Turan Neşriyat Yurdu. 